\title{
EFEKT MICRODACYNU V PROCESE HOJENIA CHRONICKÝCH RÁN
}

\author{
L'uboslava Pavelová, Erika Krištofová, Jozefína Mesárošová, Dana Zrubcová, \\ Gabriela Vörösová, Andrea Solgajová, Melánie Bet'ková \\ Katedra ošetrovatel'stva, FSVaZ, UKF v Nitre \\ lpavelova2@ukf.sk.ekristofova@ukf.sk.jmesarosova@ukf.sk.dzrubcova@ukf.sk. \\ gvorosova@ukf.sk, asolgajova@ukf.sk. mbetkova@ukf.sk
}

\begin{abstract}
Abstrakt: Východiská: Proces hojenia nie je ovplyvnený iba samotným ošetrovaním rany, ale sú prítomné d'alšie faktory, ktoré ovplyvňujú hojenie rán.

Ciel': Zhodnotenie procesu hojenia chronických rán pomocou hydrogélu Microdacyn a vplyvu d'alších faktorov.

Metódy: Výskumnú vzorku tvorilo celkovo 124 pacientov z agentúr domácej ošetrovatel'skej starostlivosti (57 \%) a z kliniky chirurgie a cievnej chirurgie (43\%) FN v Nitre. Metódou zberu dát bola metóda pozorovania resp. posúdenie rany a procesu hojenia rany použitím pozorovacieho hárka Bates-Jensen podl'a odporúčania autoriek Pokorná, Mrázová (2012). Pre hodnotenie rozdielov stavu rany v troch časových bodoch bol použitý Studentov t-test pre závislé výbery. Pre skúmanie faktorov ovplyvňujúcich efektivitu liečby bola použitá metóda viacnásobnej lineárnej regresie.

Výsledky: Kvantitatívne hodnotenie procesu hojenie rán prebiehalo v 3 hlavných etapách. Medzi jednotlivými etapami hojenia rán boli zistené štatisticky významné rozdiely a najväčší posun v celkovom skóre bol zaznamenaný medzi prvou a druhou etapou merania. Vo všetkých etapách boli zaznamenané štatisticky významné rozdiely vo všetkých 13 kategóriách (vlastnostiach) rany. Zhojenie rany pomocou Microdacynu sa dosiahlo v priemere za 28 dní (Min=8; Max=58). Najhoršie hojenie rán bolo vyhodnotené pri vredoch predkolenia. $\mathrm{V}$ prvej etape hojenia rán vstupoval do procesu hojenia rán negatívne faktor CRP. V druhej a tretej etape na stav rany vplývali zo systémových faktorov najmä bielkoviny, albumín a tiež CRP, horšie výsledky boli zaznamenané viac u žien. Zároveň negatívne ovplyvňoval stav rany aj diabetes mellitus. Na celkové zlepšenie stavu chronickej rany vplývala najmä hodnota bielkovín a albumínu, BMI a CRP.

Implikácie: Na základe kvantitatívnych analýz môžeme konštatovat', že hojenie rany je najviac ovplyvnené samotným lokálnym ošetrením. V jednotlivých etapách vstupujú do procesu hojenia rany aj d'alšie faktory, najmä stav bielkovín.
\end{abstract}

Kl'účové slová: Chronická rana. Microdacyn. Hydrogél. Hojenie rany. Faktory.

\section{ÚVOD}

Rana je definovaná ako narušenie integrity kože a integrity organizmu, poškodenie anatomickej štruktúry a funkcie kože spôsobené rôznymi príčinami zasahujúcimi rôzne hlboko do podkožných tkanív (Pospíšilová, 2008). Ak rana aj napriek adekvátnej terapii nepreukazuje po dobe 6-9 týždňov žiadne známky hojenia, považuje sa za chronickú ranu. Podl'a uvedenia Stryja (2008) nastala zmena v terminológií rán, a používaný termín chronickej rany zdôrazňoval iba časový faktor, nie stav rany, príčinu či prognózu. Navrhlo sa označenie non-healing wound, čiže nehojaca sa rana. Medzi nehojace sa (chronické) rany patria vredy predkolenia venóznej a arteriálnej príčiny, tlakové vredy, nazývané dekubity, diabetické defekty, napr. syndróm diabetickej nohy, 
exulcerujúce malignity, kožné ulcerácie v oblasti lymfedému, per secundam sa hojace operačné rany (Pokorná, Mrázová, 2012). Nehojace sa rany sú charakteristické stagnáciou hojenia v priebehu týždňov až mesiacov. Akceptovaná definícia Európskej asociácie pre manažment rán (EWMA) udáva, že ide o trvanie defektu minimálne 6 týždňov, nie však viac ako 53 týždňov. Podl'a uvedenia Sokola (2009) sa nehojace rany nezahoja skôr ako za 9 týždňov aj napriek lokálnej či kauzálnej terapii (German et al., 2002).

Dôvodov nehojenia je mnoho, ale za primárne možno považovat' najmä bakteriálnu kolonizáciu, bielkovinový status pacienta a jeho celkový stav. K d’alším príčinám ovplyvňujúcim proces hojenia patria patologický tlak, metabolické poruchy, malígne ochorenie, porucha krvotvorby, podvýživa, hypoxia, imunosupresie, chronické choroby (Singh, Young, McNaught, 2017). Podl'a uvedenia Stryja et al. (2011) sa tieto faktory delia na systémové a lokálne, resp. vnútorné (porucha imunitného systému, stav výživy, vitamínov a stopových prvkov, vysoký vek a pod.) a vonkajšie (farmakoterapia, infekcia, fyzikálno-chemické vplyvy a pod.).

Podstatnú rolu v procese hojenia rán zohráva aj typ vhodne zvoleného lokálneho ranového krytia (Sokol, 2009). Typ fázového hojenia rán (moist wound healing) udáva aplikáciu špecifických liečebných krytí súčasne s komplexným prístupom $\mathrm{k}$ hojeniu rany. Ak sa fázový postup pri ošetrovaní rán využíva správne a pokial' sa tieto materiály využívajú v indikácii podl’a správnosti, značne sa skracuje fáza hojenia a počet preväzov. Taktiež sa znižujú ekonomické náklady, šetrí sa čas personálu, ktorí ošetruje a zmierni sa telesná i psychická traumatizácia pacienta, pretože preväzy sú zvyčajne nebolestivé (Pokorná, Mrázová, 2012). Microdacyn $®$ je názov medzinárodnej značky produktov starostlivosti o rany založenej na technológii Microcyn, vyvinutej spoločnost'ou Oculus Innovave Sciences USA. Je to biologicky aktívna liečba na čistenie, zvlhčenie a zníženie mikrobiálnej zát’aže akútnych a chronických rán, ktoré sa t’ažko hoja, sú infikované, alebo pri iných t’ažkostiach. Microdacyn ${ }^{\circledR}$ znižuje mikrobiálnu zátaž elimináciou patogénnych jednobunkových mikroorganizmov, bez toxických alebo iných škodlivých vedl'ajších účinkov na l'udské tkanivo. Poškodzuje membránu patogénnych jednobunkových mikroorganizmov. Vol'né kyslíkové radikály mechanicky ničia enzýmy bunkovej membrány. Tento proces zodpovedá procesu fagocytózy, ktorý v l'udskom organizme usmrcuje patogénne mikroorganizmy. Na l'udské bunky Microdacyn neúčinkuje, pretože majú vel'kú hustotu, sú vel'mi početné, čo znemožňuje jeho pôsobenie. Okrem toho prispieva k zvlhčeniu prostredia rany, v dôsledku čoho sa rana rýchlejšie hojí. Nedráždi pokožku, oči, ani sliznice a eliminuje zápach. Nie je ho potrebné riedit', je ihned' pripravený na použitie. Po použití sú aktívne látky zredukované na 0 , čo znamená, že nie je nutné produkt vyhodit' do nemocničného odpadu. Microdacyn® je možné l'ahko použit’ v kombinácii s inými formami liečby rán (Microdacyn 60 ${ }^{\mathrm{TM}}$ Wound Care, 2019).

V práci sme sa zamerali na zhodnotenie efektivitu hydrogélu Microdacyn v procese hojenia chronických rán s prihliadnutím na vybrané faktory ovplyvňujúce hojenie rán.

\section{METÓDY}

Metódou zberu dát bola metóda pozorovania s použitím pozorovacieho hárka - Bates-Jensen posúdenie rany a procesu hojenia rany podl'a odporúčania autoriek Pokorná, Mrázová (2012). V rámci posúdenia rany boli zhodnotené lokalizácia a tvar rany a 13 d'alších kategórií rany: vel'kost', híba, okraje, podmíňovanie, nekrotické tkanivo, množstvo nekrózy, charakter sekrétu, množstvo sekrétu, okolie rany, periférny edém, periférna indurácia, granulané tkanivo a epitelizácia. Vo výskume boli porovnané v jednotlivých časoch posúdenia jednotlivé kategórie rany na pät'bodovej škále, a celkové skóre procesu hojenia na škále od 13 - 65, pričom 13 bodov predstavovalo regeneráciu rany a 65 bodov degeneráciu rany. Posúdenie rany bolo realizované trikrát ( $\mathrm{v}$ troch etapách, ktoré neboli presne špecifikované, pričom išlo o minimálne tri merania 
v rámci celkového zhojenia rany). Okrem hojenia rany boli sledované v každej etape hodnoty bielkovín, C reaktívneho proteínu a albumínu v sére a BMI.

Výskumnú vzorku tvorilo celkovo 124 pacientov v starostlivosti vo vybraných zdravotníckych zariadeniach, v agentúrach domácej ošetrovatel'skej starostlivosti (57 \%) a z kliniky chirurgie a cievnej chirurgie (43\%), z toho $52 \%$ mužov a $48 \%$ žien. Priemerný vek bol 69,17 roku (SD = 16,74). Vzhl'adom na rôznorodost' chronických rán boli špecifikované na základe lekárskej diagnózy stanovenej podl'a MKCH-10: L02.4 - Kožný abces, furbunkul, karbunkul končatiny (16 \%); L89 - Dekubitus (18 \%); L97 - Vred predkolenia (14 \%) a I70.2 - Ateroskleróza končatinových artérií (52\%).

Pre spracovanie výsledkov bol použitý štatistický program IBM SPSS 24.0. Pre analýzu dát boli použité Studentov t-test pre závislé výbery a metóda viacnásobnej lineárnej regresie.

\section{VÝSLEDKY}

Medzi jednotlivými etapami hojenia rán boli zistené štatisticky významné rozdiely v celkovom skóre hojenia chronických rán (tab.1), pričom boli porovnávané všetky tri etapy navzájom, pričom najväčší posun v celkovom skóre podl'a priemerných hodnôt bol zaznamenaný medzi prvom a druhou etapou (celkové skóre procesu hojenia bolo posudzované na škále od 13 do 65, pričom 13 bodov predstavuje regeneráciu rany a 65 bodov degeneráciu rany).

Tab 1 Celkové skóre hojenia rán v troch etapách

\begin{tabular}{lcccccc}
\hline & $\mathrm{M}$ & $\mathrm{SD}$ & $\mathrm{R}$ & $\mathrm{p}(\mathrm{r})$ & $\mathrm{T}$ & $\mathrm{p}(\mathrm{t})$ \\
\hline $\begin{array}{l}\text { 1. etapa } \\
\text { hojenia }\end{array}$ & 31,02 & 8,96 & $\mathbf{0 , 8 8 7}$ & $<, \mathbf{0 0 1}$ & $\mathbf{8 , 6 1 3}$ & $<, \mathbf{0 0 1}$ \\
$\begin{array}{l}\text { 2. etapa } \\
\text { hojenia }\end{array}$ & 25,06 & 8,33 & & & & \\
\hline $\begin{array}{l}\text { 1. etapa } \\
\text { hojenia }\end{array}$ & 31,02 & 8,96 & $\mathbf{0 , 7 6 8}$ & $\mathbf{< , 0 0 1}$ & $\mathbf{1 2 , 4 8 2}$ & $<, \mathbf{0 0 1}$ \\
$\begin{array}{l}\text { 3. etapa } \\
\text { hojenia }\end{array}$ & 19,67 & 8,22 & & & & \\
\hline $\begin{array}{l}\text { 2. etapa } \\
\text { hojenia }\end{array}$ & 25,06 & 8,33 & $\mathbf{0 , 8 8 2}$ & $<, \mathbf{0 0 1}$ & $\mathbf{9 , 1 4}$ & $<, \mathbf{0 0 1}$ \\
$\begin{array}{l}\text { 3. etapa } \\
\text { hojenia }\end{array}$ & 19,67 & 8,22 & & & & \\
\hline
\end{tabular}

Ďalším analyzovaným faktorom v procese hojenia rany bolo druh, resp. pôvod rany (lekárska diagnóza). Vyhodnotenie prebiehalo v troch etapách, pričom štatisticky významný rozdiel medzi jednotlivými ranami bol zaznamenaný iba v druhej etape hojenia. Najhoršie hojenie rany v druhej etape bolo charakteristické pre vredy predkolenia (L98.4 Chronický vred kože, L98.9 Choroba kože a podkožného tkaniva bližšie neurčená) (tab.2). 
Tab 2 Celkové skóre hojenia rán v troch etapách podl’a typu rany

\begin{tabular}{|c|c|c|c|c|c|}
\hline & & $\mathrm{M}$ & SD & $\mathrm{F}$ & $\mathrm{p}$ \\
\hline \multirow[t]{5}{*}{ 1.etapa } & Kožný abces furbunkul, karbunkul končatiny & 30,11 & 6,05 & 0,60 & 0,620 \\
\hline & Dekubitus & 27,50 & 6,38 & & \\
\hline & Vred & 33,00 & 7,69 & & \\
\hline & Ateroskeróza končatinových tepien & 30,24 & 10,11 & & \\
\hline & Spolu & 30,13 & 8,61 & & \\
\hline \multirow[t]{5}{*}{ 2.etapa } & Kožný abces furbunkul, karbunkul končatiny & 23,00 & 3,71 & 2,82 & 0,048 \\
\hline & Dekubitus & 22,44 & 4,07 & & \\
\hline & Vred & 31,38 & 9,58 & & \\
\hline & Ateroskeróza končatinových tepien & 24,11 & 7,94 & & \\
\hline & Spolu & 24,72 & 7,56 & & \\
\hline \multirow[t]{5}{*}{ 3.etapa } & Kožný abces furbunkul, karbunkul končatiny & 16,25 & 4,30 & 1,05 & 0,381 \\
\hline & Dekubitus & 16,22 & 2,11 & & \\
\hline & Vred & 21,14 & 10,98 & & \\
\hline & Ateroskeróza končatinových tepien & 19,33 & 7,41 & & \\
\hline & Spolu & 18,55 & 7,03 & & \\
\hline
\end{tabular}

Vo všetkých troch etapách hojenia rany je zaznamenaný posun v celkovom skóre hojenia rany, pričom najlepšie hodnoty blížiace sa k regenerácii rany sú zaznamenané v tretej etape hojenia (celkové skóre procesu hojenia bolo posudzované na škále od 13 do 65, pričom 13 bodov predstavuje regeneráciu rany a 65 bodov degeneráciu rany).

Ďalšou oblast'ou skúmania bolo hodnotenie vplyvu viacerých nezávislých premenných (vek, pohlavie, BMI, bielkoviny, albumín, CRP a pridružená lekárska diagnóza) na závislú premennú (hojenie chronickej rany).

Prvý blok regresných analýz bol realizovaný za účelom zhodnotenia vplyvu faktorov na stav rany. V 1. etape hojenia rany je stav rany ovplyvnený najmä vysokou hodnotou CRP. Pričom d'alšie systémové faktory so stavom rany nesúviseli (Tab.3). Aj pri zohl'adnení d'alšieho faktora pridružená lekárska diagnóza je výsledok rovnaký, iba hodnota CRP ovplyvňuje stav rany spomedzi sledovaných systémových faktorov. 
Tab 3 Vplyv vybraných faktorov na proces hojenia rany - 1. etapa

\begin{tabular}{|c|c|c|c|c|c|c|}
\hline & & $\mathrm{R}$ & Adj R2 & $\mathrm{F}$ & $\mathrm{p}$ & \\
\hline Model 1 & Faktory) & 0,295 & 0,203 & 3,20 & 0,010 & \\
\hline Model 2 & Faktory, DG) & 0,325 & 0,184 & 2,30 & 0,033 & \\
\hline Závislá pre & nenná: 1.etapa & ia rany & & & & \\
\hline & & B & SE(B) & $\mathrm{B}$ & $\mathrm{t}$ & $\mathrm{p}$ \\
\hline Model 1 & Vek & 0,011 & 0,058 & 0,026 & 0,198 & 0,844 \\
\hline & Pohlavie & 1,907 & 2,089 & 0,118 & 0,913 & 0,366 \\
\hline & BMI & $-0,095$ & 0,271 & $-0,049$ & $-0,351$ & 0,728 \\
\hline & Bielkoviny1 & $-0,082$ & 0,096 & $-0,142$ & $-0,853$ & 0,398 \\
\hline & Albumíny1 & 0,211 & 0,180 & 0,194 & 1,175 & 0,246 \\
\hline & CRP1 & 0,073 & 0,020 & 0,587 & 3,639 & 0,001 \\
\hline Model 2 & Vek & 0,005 & 0,059 & 0,011 & 0,085 & 0,933 \\
\hline & Pohlavie & 1,677 & 2,151 & 0,104 & 0,780 & 0,440 \\
\hline & BMI & $-0,159$ & 0,279 & $-0,082$ & $-0,570$ & 0,571 \\
\hline & Bielkoviny1 & $-0,093$ & 0,098 & $-0,161$ & $-0,946$ & 0,349 \\
\hline & Albumíny1 & 0,259 & 0,193 & 0,237 & 1,340 & 0,187 \\
\hline & CRP1 & 0,081 & 0,022 & 0,650 & 3,589 & 0,001 \\
\hline & P_DM & $-1,253$ & 2,632 & $-0,068$ & $-0,476$ & 0,637 \\
\hline & P_Hypertenzia & 1,165 & 2,045 & 0,075 & 0,570 & 0,572 \\
\hline & P_ISCH & 2,812 & 2,744 & 0,137 & 1,025 & 0,311 \\
\hline
\end{tabular}

Závislá premenná: 1.etapa hojenia rany

V 2. etape hojenia rany sme zistili, že na stav rany vplývajú zo systémových faktorov najmä pohlavie, bielkoviny, albumín a CRP. Horšie výsledky sú u žien, pacientov s nízkou hodnotou bielkovín a albumínu a vysokou hodnotou CRP (Tab.4). Aj pri zohl'adnení d'alšieho faktora pridružená lekárska diagnóza je výsledok rovnaký, pričom negatívne ovplyvňuje stav rany v tejto etape aj prítomnost' pridruženého ochorenia diabetes mellitus.

Tab 4 Vplyv vybraných faktorov na proces hojenia rany - 2. etapa

\begin{tabular}{|c|c|c|c|c|c|c|}
\hline & & $\mathrm{R}$ & Adj R2 & $\mathrm{F}$ & $\mathrm{p}$ & \\
\hline \multicolumn{2}{|c|}{ Model 1 (Faktory) } & 0,429 & 0,351 & 5,51 & $<, 001$ & \\
\hline \multicolumn{2}{|c|}{ Model 2 (Faktory, DG) } & 0,497 & 0,386 & 4,50 & $<, 001$ & \\
\hline \multicolumn{7}{|c|}{ Závislá premenná: 2.etapa hojenia rany } \\
\hline & & $\mathrm{B}$ & SE(B) & $\mathrm{B}$ & $\mathrm{t}$ & $\mathrm{p}$ \\
\hline \multirow[t]{6}{*}{ Model 1} & Vek & 0,017 & 0,054 & 0,039 & 0,316 & 0,753 \\
\hline & Pohlavie & 3,021 & 1,677 & 0,213 & 1,802 & 0,034 \\
\hline & BMI & $-0,232$ & 0,223 & $-0,136$ & $-1,043$ & 0,303 \\
\hline & Bielkoviny2 & $-0,297$ & 0,080 & $-0,570$ & $-3,715$ & 0,001 \\
\hline & Albumíny2 & $-0,610$ & 0,156 & $-0,624$ & $-3,915$ & $<, 001$ \\
\hline & & & 44 & & & \\
\hline
\end{tabular}




\begin{tabular}{llccccc} 
& CRP2 & $\mathbf{0 , 0 9 4}$ & $\mathbf{0 , 0 2 3}$ & $\mathbf{0 , 5 9 8}$ & $\mathbf{4 , 0 7 9}$ & $<, 001$ \\
\hline Model 2 & Vek & 0,030 & 0,053 & 0,068 & 0,560 & 0,578 \\
& Pohlavie & 2,709 & 1,655 & 0,191 & 1,637 & 0,109 \\
& BMI & $-0,278$ & 0,219 & $-0,162$ & $-1,270$ & 0,211 \\
Bielkoviny2 & $\mathbf{- 0 , 3 2 5}$ & $\mathbf{0 , 0 8 0}$ & $\mathbf{- 0 , 6 2 3}$ & $\mathbf{- 4 , 0 8 3}$ & $<, 001$ \\
& Albumíny2 & $\mathbf{- 0 , 6 6 8}$ & $\mathbf{0 , 1 5 6}$ & $\mathbf{- 0 , 6 8 3}$ & $\mathbf{- 4 , 2 8 1}$ & $<, \mathbf{0 0 1}$ \\
CRP2 & $\mathbf{0 , 0 9 7}$ & $\mathbf{0 , 0 2 3}$ & $\mathbf{0 , 6 1 7}$ & $\mathbf{4 , 3 1 1}$ & $<, \mathbf{0 0 1}$ \\
P_DM & $\mathbf{4 , 3 6 5}$ & $\mathbf{1 , 9 3 3}$ & $\mathbf{0 , 2 6 2}$ & $\mathbf{2 , 2 5 8}$ & $\mathbf{0 , 0 2 9}$ \\
& P_Hypertenzia & 0,156 & 1,564 & 0,011 & 0,100 & 0,921 \\
& P_ISCH & 2,576 & 2,120 & 0,143 & 1,215 & 0,231 \\
\hline
\end{tabular}

Závislá premenná: 2.etapa hojenia rany

V 3. etape na stav rany vplývajú zo systémových faktorov najmä pohlavie, BMI, bielkoviny a CRP. Horšie výsledky boli znovu zistené u žien, u pacientov s vysokou hodnotou BMI, nízkou hodnotou bielkovín a vysokou hodnotou CRP (Tab.5). Aj pri zohl'adnení d’alšieho faktora - pridružená lekárska diagnóza je výsledok rovnaký, pričom negatívne ovplyvňuje stav rany aj prítomnost' diabetes mellitus.

Tab 5 Vplyv vybraných faktorov na proces hojenia rany - 3. etapa

\begin{tabular}{|c|c|c|c|c|c|c|}
\hline & & $\mathrm{R}$ & Adj R2 & $\mathrm{F}$ & $\mathrm{p}$ & \\
\hline Model 1 & Faktory) & 0,612 & 0,554 & 10,51 & $<, 001$ & \\
\hline Model 2 & Faktory, DG) & 0,700 & 0,627 & 9,60 & $<, 001$ & \\
\hline Závislá pre & nenná: 3.etapa & nia rany & & & & \\
\hline & & B & SE(B) & $\beta$ & $\mathrm{t}$ & $\mathrm{p}$ \\
\hline Model 1 & Vek & 0,022 & 0,044 & 0,053 & 0,484 & 0,631 \\
\hline & Pohlavie & 4,227 & 1,430 & 0,307 & 2,956 & 0,005 \\
\hline & BMI & 0,448 & 0,180 & 0,271 & 2,496 & 0,017 \\
\hline & Bielkoviny3 & $-0,277$ & 0,065 & $-0,576$ & $-4,248$ & $<, 001$ \\
\hline & Albumíny3 & $-0,137$ & 0,144 & $-0,130$ & $-0,951$ & 0,347 \\
\hline & CRP3 & 0,060 & 0,022 & 0,316 & 2,667 & 0,011 \\
\hline Model 2 & Vek & 0,013 & 0,041 & 0,031 & 0,308 & 0,760 \\
\hline & Pohlavie & 4,052 & 1,355 & 0,294 & 2,990 & 0,005 \\
\hline & BMI & 0,484 & 0,168 & 0,293 & 2,875 & 0,007 \\
\hline & Bielkoviny3 & $-0,285$ & 0,060 & $-0,593$ & $-4,714$ & $<, 001$ \\
\hline & Albumíny3 & 0,170 & 0,132 & 0,162 & 1,290 & 0,205 \\
\hline & CRP3 & 0,063 & 0,021 & 0,333 & 3,055 & 0,004 \\
\hline & P_DM & 4,334 & 1,504 & 0,272 & 2,881 & 0,007 \\
\hline & P_Hypertenzia & 1,309 & 1,204 & 0,100 & 1,087 & 0,284 \\
\hline & P_ISCH & 2,499 & 1,693 & 0,144 & 1,476 & 0,148 \\
\hline
\end{tabular}

Závislá premenná: 3.etapa hojenia rany 
Ďalší blok regresných analýz bol realizovaný za účelom zhodnotenia vplyvu faktorov proces hojenia rany medzi jednotlivými etapami. Zlepšenie stavu rany medzi 1. a 2. etapou bol na základe našich zistení ovplyvnený najmä hodnotami bielkovín a albumínu z prvej etapy (tab.6). Pričom, čím boli ich hodnoty vyššie, tak bolo zaznamenané lepšie hojenie rany. Aj pri zohl'adnení d'alšieho faktora - pridružená lekárska diagnóza je výsledok rovnaký.

Tab 6 Vplyv vybraných faktorov na proces hojenia rany - posun medzi 1. a 2. etapou

\begin{tabular}{|c|c|c|c|c|c|c|}
\hline & & $\mathrm{R}$ & Adj R2 & $\mathrm{F}$ & $\mathrm{p}$ & \\
\hline Model 1 & Faktory) & 0,458 & 0,366 & 4,94 & 0,001 & \\
\hline Model 2 & Faktory, DG) & 0,495 & 0,353 & 3,49 & 0,004 & \\
\hline Závislá pre & nenná: Zlepšeni & dzi 1.a & tapou & & & \\
\hline & & $\mathrm{B}$ & SE(B) & B & $\mathrm{t}$ & $\mathrm{p}$ \\
\hline Model 1 & Vek & 0,009 & 0,038 & 0,033 & 0,242 & 0,810 \\
\hline & Pohlavie & 1,984 & 1,179 & 0,221 & 1,683 & 0,101 \\
\hline & BMI & $-0,086$ & 0,146 & $-0,085$ & $-0,585$ & 0,562 \\
\hline & Bielkoviny1 & 0,114 & 0,053 & 0,385 & 2,164 & 0,037 \\
\hline & Albumíny1 & 0,423 & 0,094 & 0,748 & 4,509 & $<, 001$ \\
\hline & CRP1 & $-0,002$ & 0,010 & $-0,038$ & $-0,243$ & 0,810 \\
\hline Model 2 & Vek & 0,020 & 0,040 & 0,073 & 0,495 & 0,624 \\
\hline & Pohlavie & 2,205 & 1,216 & 0,246 & 1,813 & 0,051 \\
\hline & BMI & $-0,046$ & 0,150 & $-0,046$ & $-0,308$ & 0,760 \\
\hline & Bielkoviny1 & 0,108 & 0,054 & 0,366 & 1,989 & 0,035 \\
\hline & Albumíny1 &,- 406 & 0,101 & 0,717 & 4,000 & $<, 001$ \\
\hline & CRP1 & $-0,006$ & 0,012 & $-0,092$ & $-0,517$ & 0,609 \\
\hline & P_DM & $-0,274$ & 1,457 & 0,028 & 0,188 & 0,852 \\
\hline & P_Hypertenzia & $-0,475$ & 1,274 & $-0,054$ & $-0,373$ & 0,712 \\
\hline & P_ISCH & $-2,003$ & 1,478 & $-0,191$ & $-1,355$ & 0,185 \\
\hline
\end{tabular}

Závislá premenná: Zlepšenie medzi 1. a 2. etapou

Zlepšenie stavu ranu medzi 2. a 3. etapou bol na základe našich zistení ovplyvnený najmä BMI a hodnotami a albumínu a CRP z druhej etapy (tab.7). Výraznejšie zlepšenie bolo zistené pri nižších hodnotách BMI a vyšších hodnotách Albumínov a CRP. Aj pri zohl'adnení d'alšieho faktora pridružená lekárska diagnóza bol výsledok bez zmeny. 
Tab 7 Vplyv vybraných faktorov na proces hojenia rany - posun medzi 2. a 3. etapou

\begin{tabular}{|c|c|c|c|c|c|c|}
\hline & & $\mathrm{R}$ & Adj R2 & $\mathrm{F}$ & $\mathrm{P}$ & \\
\hline Model 1 & Faktory) & 0,400 & 0,276 & 3,23 & 0,015 & \\
\hline Model 2 & Faktory, DG) & 0,419 & 0,218 & 2,09 & 0,069 & \\
\hline Závislá pre & nenná: Zlepšenie & dzi $2 . a$ & tapou & & & \\
\hline & & $\mathrm{B}$ & SE(B) & B & $\mathrm{t}$ & $\mathrm{p}$ \\
\hline Model 1 & Vek & 0,015 & 0,043 & 0,058 & 0,353 & 0,727 \\
\hline & Pohlavie & 2,420 & 1,350 & 0,277 & 1,793 & 0,051 \\
\hline & BMI & $-0,356$ & 0,161 & $-0,367$ & $-2,218$ & 0,030 \\
\hline & Bielkoviny2 & 0,039 & 0,057 & 0,139 & 0,677 & 0,504 \\
\hline & Albumíny2 & 0,250 & 0,124 & 0,428 & 2,022 & 0,042 \\
\hline & CRP2 & 0,037 & 0,017 & 0,411 & 2,226 & 0,024 \\
\hline Model 2 & Vek & 0,016 & 0,047 & 0,062 & 0,344 & 0,733 \\
\hline & Pohlavie & 2,730 & 1,488 & 0,313 & 1,835 & 0,051 \\
\hline & BMI & $-0,360$ & 0,172 & $-0,370$ & $-2,089$ & 0,037 \\
\hline & Bielkoviny2 & 0,041 & 0,060 & 0,148 & 0,685 & 0,499 \\
\hline & Albumíny2 & 0,249 & 0,129 & 0,426 & 1,928 & 0,045 \\
\hline & CRP2 & 0,039 & 0,017 & 0,428 & 2,220 & 0,025 \\
\hline & P_DM & 1,138 & 1,611 & 0,115 & 0,706 & 0,486 \\
\hline & P_Hypertenzia & $-0,361$ & 1,415 & $-0,043$ & $-0,255$ & 0,801 \\
\hline & P_ISCH & 0,976 & 1,77 & 0,099 & 0,552 & 0,586 \\
\hline
\end{tabular}

Závislá premenná: Zlepšenie medzi 2. a 3. etapou

Zlepšenie stavu ranu medzi 1. a 3. etapou bol na základe našich zistení ovplyvnený najmä hodnotami bielkovín z prvej etapy (začiatok liečby) (tab.8), pričom väčšie zlepšenie bolo zistené pri vyšších hodnotách bielkovín. Pri zohl’adnení d’alšieho faktora - pridružená lekárska diagnóza nebol žiadny z posudzovaných systémových faktorov hodnotený ako štatisticky významný.

Tab 8 Vplyv vybraných faktorov na proces hojenia rany - posun medzi 1. a 3. etapou

\begin{tabular}{lcccc}
\hline & $\mathrm{R}$ & Adj R2 & $\mathrm{F}$ & $\mathrm{P}$ \\
\hline Model 1 (Faktory) & 0,258 & 0,109 & 1,74 & 0,147 \\
Model 2 (Faktory, DG) & 0,298 & 0,064 & 1,28 & 0,295 \\
\hline
\end{tabular}

Závislá premenná: Zlepšenie medzi 1. a 3. etapou

\begin{tabular}{llccccc}
\hline & & $\mathrm{B}$ & $\mathrm{SE}(\mathrm{B})$ & $\beta$ & $\mathrm{t}$ & $\mathrm{p}$ \\
\hline Model 1 & Vek & 0,004 & 0,062 & 0,012 & 0,068 & 0,946 \\
& Pohlavie & 4,612 & 2,162 & 0,365 & 2,133 & 0,052 \\
& BMI & $-0,146$ & 0,255 & $-0,105$ & $-0,570$ & 0,573 \\
& Bielkoviny1 & $\mathbf{0 , 1 9 0}$ & $\mathbf{0 , 0 9 1}$ & $\mathbf{0 , 4 7 9}$ & $\mathbf{2 , 0 7 9}$ & $\mathbf{0 , 0 4 6}$ \\
& Albumíny1 & 0,163 & 0,175 & 0,195 & 0,931 & 0,359 \\
& CRP1 & 0,021 & 0,018 & 0,233 & 1,196 & 0,241 \\
\hline \multicolumn{5}{c}{47}
\end{tabular}


Pomáhajúce profesie, roč. 2, č. 2, 2019, 40-51

\begin{tabular}{llccccc}
\hline Model 2 & Vek & $-0,010$ & 0,070 & $-0,027$ & $-0,138$ & 0,892 \\
& Pohlavie & 5,196 & 2,389 & 0,412 & 2,175 & 0,051 \\
& BMI & $-0,261$ & 0,280 & $-0,189$ & $-0,932$ & 0,359 \\
& Bielkoviny1 & 0,167 & 0,098 & 0,420 & 1,700 & 0,101 \\
& Albumíny1 & 0,124 & 0,200 & $-0,148$ & 0,621 & 0,540 \\
& CRP1 & 0,025 & 0,020 & 0,280 & 1,275 & 0,213 \\
& P_DM & $-0,885$ & 2,726 & $-0,064$ & $-0,325$ & 0,748 \\
& P_Hypertenzia & 1,288 & 2,282 & 0,106 & 0,564 & 0,577 \\
& P_ISCH & 2,703 & 2,807 & 0,188 & 0,963 & 0,344 \\
\hline
\end{tabular}

Závislá premenná: Zlepšenie medzi 1. a 3. etapou

\section{DISKUSIA}

Našimi zistenia prinášame podporu evidence v procese hojenia chronických rán resp. nehojacich sa rán. Podl’a uvedenia Pokornej a Mrázovej (2012) sú najčastejšou príčinou nehojacich sa rán troficky zmenené tkanivá na základe predchádzajúceho ochorenia či postihnutia (cievny pôvod). Zovšeobecnitel'nost' našich zistení môže podporovat' zloženie výberového súboru, kde najväčšou vzorkou, viac ako polovica súboru boli pacienti s nehojacimi sa ranami pôvodom cievneho poškodenia, konkrétne s lekárskou diagnózou podl'a MKCH-10 Ateroskleróza končatinových artérií (I70.2).

Posúdenia procesu hojenie rán prebiehalo v 3 hlavných etapách. Medzi jednotlivými etapami hojenia rán boli zistené štatisticky významné rozdiely a najväčší posun v celkovom skóre bol zaznamenaný medzi prvou a druhou etapou. Rovnako vo všetkých 13 kategóriách (vlastnostiach) rany boli vo všetkých etapách zaznamenané štatisticky významné rozdiely. Zhojenie, ktoré sme kvantifikovali v rámci celkového skóre na posudzovanej škále v hodnote 13, čo predstavovalo regeneráciu rany sa dosiahlo minimálne za 8 dní, maximálne za 58 dní a v priemere $A M=28,25$ dňa. Podl'a uvedenia Sokola (2009) sa nehojace rany nezahoja skôr ako za 9 týždňov aj napriek lokálnej či kauzálnej terapii (German et al., 2002). Podl'a uvedenia Pokornej a Mrázovej (2012) ak sa fázový postup ošetrovania rán využíva správne a pokial' sa tieto materiály využívajú v indikácii podl'a správnosti, značne sa skracuje fáza hojenia. Naše zistenia potvrdzujú podstatne menší čas na dosiahnutie zhojenia chronickej rany, a to skoro o polovicu kratšie ako uvádzajú German et al.(2002). Najhoršie hojenie rany bolo vyhodnotené v 2. etape merania najviac v kategórii - vredy predkolenia. Najlepšie hodnoty hojenia rany (regenerácia rany) boli zaznamenané v poslednej etape hojenia.

Proces hojenia nie je ovplyvnený iba samotným ošetrovaním rany, ale i d’alšími faktormi, preto sme sa zamerali aj na zhodnotenie efektivity hydrogélu Microdacyn v procese hojenia chronických rán s prihliadnutím na vybrané faktory ovplyvňujúce hojenie rán. V literatúre sú popisované viaceré systémové faktory ako napríklad základná príčina vzniku rany, pridružené ochorenia (ischemická choroba srdca, hypertenzia, respiračné ochorenia, diabetes mellitus, autoimunitné ochorenia, malabsorbčné syndrómy, nádorové ochorenia, hematologické poruchy, centrálna hypoxia), vek pacienta, nutričný stav (nedostatočný prísun základných živín, dehydratácia, nedostatok vit. A, C, E, K), lieky (nepriaznivý vplyv na hojenie majú napr. cytostatiká, imunosupresíva, cytotoxické lieky, antikoagulanciá, protizápalové lieky), nedostatok spánku, psychický stav, systémová infekcia, návyky (alkohol, fajčenie, drogy) a spôsob života. Ako lokálne faktory sú najčastejšie popisované porucha hemodynamiky, híbka, vel'kost', spodina, lokalizácia, okraje rany, mikrobiálna infekcia, 
vek, hypoxia, teplota rany, cudzie telesá v rane a macerácia kože v okolí rany (Mezera, Bureš, 2018).

V prvej etape hojenia do procesu hojenia rany negatívne vstupoval faktor CRP, jeho vysoké hodnoty. V druhej etape na stav rany vplývali zo systémových faktorov najmä nízke hodnoty bielkovín, albumínu a vysoké hodnoty CRP a horšie výsledky boli zaznamenané viac u žien. Zároveň negatívne ovplyvňoval stav rany aj diabetes mellitus. Pre tretiu etapu hojenia rán je vplyv faktorov podobný ako bol v druhej etape. Diabetes mellitus je považovaný za systémový faktor ovplyvňujúci hojenie rán, nakol'ko sú ovplyvnené bunkové funkcie ako defektná imunita T buniek, chemotaxia leukocytov, fagocytóza, baktericídna kapacita a dysfunkcia fibroblastov a epidermálnych buniek. Súhrnne tieto nedostatky prispievajú k nedostatočnému likvidovaniu infekcie a oneskorenému hojeniu. (Fejfárová, Jirkovská a kol., 2015; Mulholland, Dunne, Mc.Carthy, 2017).

Posledná analýza bola realizovaná za účelom zhodnotenia vplyvu vybraných faktorov na posun (zlepšenie) v hojení rany. Zlepšenie stavu rany medzi prvou a druhou etapou bol na základe našich zistení ovplyvnený hodnotami bielkovín a albumínu z prvej etapy. Čím boli ich hodnoty vyššie, tým bol zaznamenaný výraznejší posun v hojení rany. Zlepšenie hojenia rany medzi druhou a tret'ou etapou bol ovplyvnený najmä nižšou hodnotu BMI a vyššími hodnotami albumínov, ako aj hodnotou CRP. Pri zdôvodnení faktora BMI v hojení rany je dôležité uviest', že obezita je mnohokrát vnútorne spojená s cukrovkou (typ 2). Kožné záhyby obsahujú mikroorganizmy, ktorým sa darí vo vlhkých oblastiach a prispievajú k infekcií tkanív. Infekcia je príkladom lokálneho faktora, ktorý je spojený s komplikovaným hojením rán. Infekcia v rane môže ovplyvnit' proces hojenia, a to predížením zápalovej fázy tkanív (Mulholland, Dunne, Mc.Carthy, 2017). Podl'a Sokola (2009) je v procese hojenia rán dôležité sledovat' BMI, a u pacientov trpiacich nadváhou je nutná úprava stravovacích návykov a zmena jedálneho lístka.

Najvýraznejší posun v zlepšení hojenia rany bol zaznamenaný medzi prvou a tret'ou etapou, kde prišlo v priemere za 28,25 dňa k regenerácii rany. Najväčšie zlepšenie bolo zistené najmä pri vyšších hodnotách bielkovín. Toto zistenie považujeme za klúčové. Podl'a Molnara et al. (2014) je dôležitá kontrola bielkovín v sére, ako aj hodnotenie albumínu a C-reaktívneho proteínu na hodnotenie stavu bielkovín v organizme, nakol'ko pacienti s identifikovaným deficitom bielkovín sú často spájaní so zlým hojením a výskytom komplikácií rany. Prioritné je pochopenie, resp. rozpoznanie výživových potrieb pacienta s nehojacimi sa ranami. Bielkoviny patria k makronutrientom, ktoré sú podl’a smerníc a štandardov ASPEN definované ako „výživné látky prítomné $\mathrm{v}$ tele a požadované $\mathrm{v}$ najväčšom množstve. Aminokyseliny sú stavebnými kameňmi bielkovín v celom tele. Niektorí autori odporúčajú, sledovanie biochemických ukazovatel'ov pri chronických ranách najmä v kontexte s intervenciou doplnenia špecifickými doplnkov, ako sú antioxidanty, vitamín A a vitamín $\mathrm{D}$, ktoré podporujú proces hojenia. Najmä prístupy metabolického manažmentu v starostlivosti o chronickú ranu nie sú všeobecne univerzálne ako pre pacienta sakútnou ranou. Všetky mikro a makronutrienti sú považované ako dôležité spolufaktory ovplyvňujúce enzymatické procesy pri hojení rán (Molnar et al., 2014).

Prekvapivým zistením bolo, že vek sa ako faktor v žiadnej analýze nepreukazoval ako významný faktor, napriek tomu, že v chirurgickej praxi je typické, že starší majú horšie hojenie kvôli tenšej epidermálnej vrstve a majú pomalšie zápalové, migračné a proliferačné reakcie. Aj riziko komplikácií rany, ako je napríklad dehiscencia je u starších pacientov vyššie (Singh, Young, McNaught, 2017). Jedným z dôvodov horšieho hojenia rán môže byt' aj malnutrícia u starých l'udí.

\section{ZÁVER}


Hojenie chronickej rany je ovplyvnené nielen samotným lokálnym ošetrením, ale aj d’alšími faktormi, ktoré v jednotlivých etapách hojenia vstupujú do procesu. Microdacyn predstavuje špecifické liečebné krytie, ktoré významným spôsobom skracuje fáza hojenia a počet preväzov. Pri jeho použití v procese hojenia chronických rán je potrebné hodnotit’aj faktory, ktoré ovplyvňujú proces hojenia. Podl'a našich zistení ide najmä o hodnoty bielkovín, albumínu a C-reaktívneho proteínu. Odporúča sa posúdit' aj výživu, stav BMI (podvýživa, obezita) a zastúpenie d'alších mikronutrientov. Všetky tieto faktory ovplyvňujú metabolické procesu kolagénu a zápalu v procese hojenia rán, čím ovplyvňujú samotné hojenie rany.

\section{LITERATÚRA}

German, G. et al. (2002): Kompendium rán a ich ošetrovania. Hartmann - Rico a.s., 123s.

Fejfárová, V., Jirkovská, A. a kol. (2015): Léčba syndrómu diabetické nohy odlehčením. Maxdorf, 352 S.

Hlinková, E., Nemcová, J.,Miertová, M. (2015): Nehojace sa rany. Martin: Osveta, 284 s.

Mezera, V., Bureš, I. (2018): Chronické nehojící se rány v geriatrii. Vnitřní lékařství, 64(11), 10981104.

Microdacyn 60 Wound Care. 2019. [online] [vid.2019-11-18]. Dostupné z: https://www.acarehealth.sk/hojenie-ran/microdacyn-60-wound-care/

Molnar, J.A., Underdown, M.J., Clark, W.A. (2014): Nutrition and Chronic Wounds. Advances in Wound Care, 3(11), 663-681.

Mulholland, Dunne, Mc.Carthy (2017): MicroRNA as Therapeutic Targets for Chronic Wound Healing. Mol Ther Nucleic Acids. 15 (8), 46-55.

Pokorná, A., Mrázová, R. (2012): Kompendium hojení rán pro sestry. Praha: Grada, 191 s.

Pospíšilová, A. (2008): Hojení chronických ran . Standardy léčebných postupů a kvalita ve zdravotní péči. Praha: Verlag Dashófer, 2008. s.1-16.

Singh, S., Young, A., McNaught, C. (2017): The physiology of wound healing. Surgery. Basic science, 35(9), 473-477.

Sokol, R. (2009): Súčasné aspekty liečby chronických rán. Via practica, 6(6), 256-259.

Stryja J. et al. (2008): Repetitorium hojení ran. Semily: GEUM, 199 s.

Stryja J. et al. (2011): Reperitorium hojení ran 2. Semily: GEUM, 371 s.

\section{EFFECTS OF MICRODACYN IN CHRONIC WOUND HEALING}

Abstract: Background: A healing process is affected not only by wound treatment itself; other factors affecting wound healing are also present.

Objective: Evaluation of chronic wound healing with the use of Microdacyn hydrogel, and effects of other factors.

Methods: The sample consisted of 124 patients from home health care agencies (57\%) and the Clinic of Surgery and Vascular Surgery (43\%), Faculty Hospital Nitra. The data collection method was the observation method or the assessment of the wound and wound healing process using the Bates-Jensen Wound Assessment Tool as 
recommended by Pokorná and Mrázová (2012). To assess the differences in the wound status at three time points, the Student's $t$-test for dependent samples was used. A multi-linear regression method was used to study the factors influencing the effectiveness of treatment.

Results: A quantitative assessment of the wound healing process was conducted in three main stages. Statistically significant differences were found between the specific wound healing stages; the largest shift in the total score was found between the first and second stages of measurement. In all the stages, statistically significant differences in all 13 categories (properties) of the wound were detected. Wound healing with the use of Microdacyn was achieved in 28 days in average (Min = 8; Max $=58$ ). The worst wound healing was found in the venous leg ulcers. In the first stage of wound healing, the factor of CRP negatively influenced the wound healing process. In the second and third stages, the wound status was influenced by systemic factors, in particular proteins, albumin and CRP; worse results were found in females more frequently. Also diabetes mellitus negatively affected the wound status. In particular, the overall improvement in the chronic wound status was influenced by the values of proteins and albumin, BMI and CRP.

Implications: Based on the quantitative analyses, it can be stated that wound healing is most affected by local treatment itself. In the specific stages, other factors, particularly proteins, influence the wound healing process.

Keywords: Chronic wound. Microdacyn. Hydrogel. Wound healing. Factors.

Grantová podpora:

Príspevok bol podporený projektom ZML-2017/1-891:191006: Výskum efektu zdravotníckej pomôcky „Hydrogél na ošetrenie rán Microdacyn“ v procese hojenia chronických rán 